\title{
Deficiency of Vitamin D in Allergic Rhinitis: A Possible Factor in Multifactorial Disease
}

\author{
${ }^{1}$ Bhaskar Thakkar, ${ }^{2}$ Ashish Katarkar, ${ }^{3}$ Datt Modh, ${ }^{4}$ Anil Jain, ${ }^{5}$ Pankaj Shah, ${ }^{6}$ Krupal Joshi
}

\begin{abstract}
Allergic rhinitis is a common condition affecting 5 to $40 \%$ of general population and its prevalence is increasing. It is a chronic condition characterized by inflammation of nasal mucosa. As per recent studies, there is an association between serum vitamin D levels and allergic rhinitis status. Vitamin D has major role in the regulation of calcium metabolism. In addition to this, it also has a number of immunological effects and takes part in immunomodulation, which can significantly affect the outcome of allergic responses like in allergic rhinitis.
\end{abstract}

Aims and objectives: To establish the correlation between vitamin D3 serum levels and allergic rhinitis.

Materials and methods: Vitamin D levels were assessed in 23 patients with allergic rhinitis diagnosed clinically by allergic rhinitis and its impact on asthma 2008 criteria and results were compared with vitamin D status in the normal population of same region.

Results: The levels of serum vitamin D levels were significantly low in the patients of allergic rhinitis.

Conclusion: Measuring of serum levels of vitamin D could be considered in the routine assessment of patients with allergic rhinitis.

Keywords: Allergic rhinitis, Vitamin D deficiency, Calcitriol.

How to cite this article: Thakkar B, Katarkar A, Modh D, Jain A, Shah P, Joshi K. Deficiency of Vitamin D in Allergic Rhinitis: A Possible Factor in Multifactorial Disease. Clin Rhinol An Int J 2014;7(3):112-116.

Source of support: Nil

Conflict of interest: None

\footnotetext{
${ }^{1}$ Associate Professor (Pathology), ${ }^{2,4}$ Professor, ${ }^{3,6}$ Resident ${ }^{5}$ Professor and Head

${ }^{1}$ Department of ENT and Head and Neck Surgery, GMERS Medical College and Hospital, Ahmedabad, Gujarat, India

${ }^{2-5}$ Department of ENT and Head and Neck Surgery, CU Shah Medical College and Hospital, Surendra Nagar, Gujarat, India

${ }^{6}$ Department of Community Medicine, CU Shah Medical College and Hospital, Surendra Nagar, Gujarat, India
}

Corresponding Author: Ashish Katarkar, Professor Department of ENT and Head and Neck Surgery, CU Shah Medical College and Hospital, Surendra Nagar, Gujarat, India Phone: 8866148963, e-mail: ashishkatarkar@gmail.com

\section{INTRODUCTION}

Allergic rhinitis is a major atopic condition. Allergic rhinitis is a common health problem caused by inflammatory reaction after allergen exposure and associated with an immunoglobulin E (IgE) mediated immune response against allergen. It is the most common form of the noninfectious rhinitis. It is not a life-threatening condition but in most cases it interferes with the patient's personal life and imposes a substantial burden on public health in economic terms of the quality of life and productivity. ${ }^{1}$ There are good treatments available for allergic rhinitis, including antihistamines and topical corticosteroids. ${ }^{2}$ Yet, there is a need for new treatment options, particularly aiming at new targets and associated with reduced side effects. The prevalence varies among countries, probably because of geographic and aeroallergen differences. ${ }^{3-6}$ Allergic rhinitis affects between 10 and $30 \%$ of all adults and as many as $40 \%$ of children. In India, allergic rhinitis (AR) is considered to be a trivial disease, despite the fact that symptoms of rhinitis were present in $75 \%$ of children and $80 \%$ of asthmatic adults. ${ }^{7}$ One-sixth of Canadians suffer from this disorder. ${ }^{8}$

Low serum $25(\mathrm{OH})$ vitamin D levels are prevalent in every region studied (e.g. very low levels are most common in regions such as south Asia and the Middle East). ${ }^{9}$ In recent years, the worldwide increase in allergic diseases has been associated with low vitamin $\mathrm{D}$ Schauber et $\mathrm{al}^{10}$ stated that the association between low serum vitamin $\mathrm{D}$ levels and an increase in immune disorders is not coincidental. Growth in populations has resulted in people spending more times indoors, leading to less sun exposure and less cutaneous vitamin D production. ${ }^{11}$

Several studies have been designed to investigate the value of vitamin $D$ in the treatment of allergic diseases and asthma, but still the results are controversial. ${ }^{10,12,13}$

\section{MATERIALS AND METHODS}

\section{Study Design and Population}

The study included patients with allergic rhinitis, who were referred to department of ENT in our institution, during a 1 year period between December 2011 and December 2012. 
Deficiency of Vitamin D in Allergic Rhinitis: A Possible Factor in Multifactorial Disease

\begin{tabular}{lc}
\hline & Table 1: TNSS scoring system ${ }^{14}$ \\
\hline Score & 0 to 3 \\
Rhinorrhea & 0 to 3 \\
Obstruction & 0 to 3 \\
Sneezing & 0 to 3 \\
Itching & 0 to 3 \\
Anosmia & 0 to 3 \\
TNSS & Out of 15 \\
\hline
\end{tabular}

0: Absent; 1: Mild; 2: Moderate; 3: Severe

Table 3: Age distribution

\begin{tabular}{lll}
\hline Age group (years) & No. of patients & Percentage \\
\hline $20-24$ & 2 & 8.69 \\
$25-29$ & 4 & 17.39 \\
$30-34$ & 5 & 21.7 \\
$35-39$ & 3 & 13.04 \\
$40-44$ & 4 & 17.39 \\
$45-60$ & 5 & 21.7 \\
\hline Total & 23 & 100 \\
\hline
\end{tabular}

\begin{tabular}{lll}
\multicolumn{2}{c}{ Table 2: Sex distribution } \\
\hline Sex & No. of patients & Percentage \\
\hline Male & 11 & 47.82 \\
Female & 12 & 52.18 \\
\hline Total & 23 & 100 \\
\hline
\end{tabular}

Table 4: Distribution of patients according to symptoms score

\begin{tabular}{ll}
\hline Total nasal symptom score (TNSS) & No. of patients \\
\hline$>11$ & $9(39.13 \%)$ \\
7 to 10 & $13(56.52 \%)$ \\
3 to 6 & $1(4.34 \%)$ \\
0 to 2 & 0 \\
\hline
\end{tabular}

bothersome but tolerable, 3 = symptoms that is hard to tolerate. Each patients total nasal symptoms scores - TNSS were calculated by summing that patients' nasal symptoms (Table 1$) \cdot{ }^{14}$ Serum vitamin D3 levels measured using 'Cobas E 411 (fully automated) Hormone-immunoassay analyzer'. Enhanced chemiluminance method used by this instrument for measurement. Twenty-five $(\mathrm{OH}) \mathrm{D}$ levels greater than $30 \mathrm{ng} / \mathrm{ml}$ is considered as normal. While vitamin D deficiency is defined as $25(\mathrm{OH}) \mathrm{D}$ levels $<20 \mathrm{ng} / \mathrm{ml}$, vitamin D insufficiency defined as $25(\mathrm{OH}) \mathrm{D}$ levels between 20 and $30 \mathrm{ng} / \mathrm{ml}^{15}$ Patients with serum vitamin D levels $>30 \mathrm{ng} / \mathrm{ml}$ were considered as normal. Such patients were two in number.

- All the patients were thoroughly interviewed and complete ENT examination were done.

- Nasal symptoms score were recorded.

- Serum vitamin D3 levels were measured.

- Exclusion criteria concerned patients who had comorbid disease in addition to allergic rhinitis that could affect vitamin D serum levels. Such diseases included rheumatoid arthritis, cystic fibrosis, multiple sclerosis, ulcerative colitis, crohn's disease, celiac disease, rickets, osteomalacia, sarcoidosis and thyroid dysfunctions, and individuals who had received medications including corticosteroids, barbiturates, bisphosphonates, sulfasalazine, omega 3 and vitamin D components, such as calcium D were excluded.

- The study results of vitamin D serum levels in allergic rhinitis were compared with the vitamin D serum levels of normal individuals having no history of allergic rhinitis or allergic disease or any other illness that affect serum levels of vitamin $D$.

\section{MEASUREMENTS}

- Before and after treatment, patients rated their nasal symptoms (i.e. Rhinorrhea, nasal blockage, sneezing, nasal itching, anosmia) using four point scale as follows: $0=$ no symptom evident, $1=$ symptom present but not bothersome, 2 = definite symptom that is

\section{Statistical Analysis}

Data were analyzed using SPSSR software (Version 17.0; SPSS, USA). Descriptive statistical analysis and nonparametric statistical tests were used.

\section{RESULTS}

Among 23 patients, male patients were 11 (47.82\%) and female patients were 12 (52.18\%) as shown in Table 2. The mean age was $35.3 \pm 9.63$ years. Distribution of patients according to age is summarized in Table 3.

The mean vitamin D level was $19.52 \pm 7.35 \mathrm{ng} / \mathrm{ml}$ in 23 patients of allergic rhinitis. Of the 23 patients evaluated, 9 (39.13\%) were experiencing severe signs and symptoms of the allergic rhinitis (TNSS >11), 13 (56.52\%) were considered to be moderate (TNSS: 7-10) and 1 (4.34\%) were classified as mild (TNSS: 3-6) (Table 4).

Twenty-five $(\mathrm{OH}) \mathrm{D}$ levels greater than $30 \mathrm{ng} / \mathrm{ml}$ is considered as normal. While vitamin $\mathrm{D}$ deficiency is defined as $25(\mathrm{OH})$ D levels $<20 \mathrm{ng} / \mathrm{ml}$, vitamin D insufficiency is defined as $25(\mathrm{OH}) \mathrm{D}$ levels between 20 and $30 \mathrm{ng} / \mathrm{ml}$ (Table 5). ${ }^{14}$

The results of the study when compared to the control group consist of 23 normal individuals of age group ranging from 15 to 60 years having no history of allergic 
Table 5: Grading according to vitamin D level ${ }^{15}$

\begin{tabular}{lll}
\hline Vit. D status & Serum level $(\mathrm{ng} / \mathrm{ml})$ & No. of patients \\
\hline Normal & $>30$ & $2(8.69 \%)$ \\
Insufficient & $20-30$ & $6(26.08 \%)$ \\
Deficient & $<20$ & $15(65.21 \%)$ \\
\hline Total & - & 23 \\
\hline
\end{tabular}

rhinitis or other allergic disease or any other illness that can affect serum levels of vitamin D, we found there was significant difference. Mean serum vitamin D level of the normal individuals $34.94 \pm 15.65 \mathrm{ng} / \mathrm{ml}$, while it was 19.52 $\pm 7.35 \mathrm{ng} / \mathrm{ml}$ in 23 patients of allergic rhinitis being low with statistically significant at $p$-value of $0.00059(<0.05)$ suggesting deficiency in patients of allergic rhinitis.

Moreover, the deficiency was more pronounced in the patients having severe allergic rhinitis as shown in Table 6, the patients with TNSS > 11 were having mean vitamin D level $16.88 \mathrm{ng} / \mathrm{ml}$.

\section{DISCUSSION}

In allergic rhinitis symptoms arise as a result of local inflammation induced by aeroallergens such as pollens, molds, animal dander and house dust mites. The immune response involves the release of inflammatory mediators and the activation and recruitment of different inflammatory cells to the nasal mucosa. ${ }^{16}$ Infiltration of inflammatory cells is evident in both seasonal and perennial form, although the magnitude of these cellular changes is somehow different in seasonal and perennial allergic rhinitis. ${ }^{17}$

A characteristic feature of allergic inflammation is local accumulation of inflammatory cells including $\mathrm{T}$ lymphocytes, mast cells, eosinophils, basophils and neutrophils. ${ }^{18}$ Release of various mediators from these cells is responsible for the symptoms of allergic rhinitis. ${ }^{20}$ Accumulation of additional inflammatory cells such as eosinophils and $\mathrm{T}$ cells occurs in response to various chemokines and cytokines.

\section{Vitamin D and Immunomodulation}

Vitamin D has immunomodulatory steroid hormone properties and directly affects dendritic cell, monocyte, macrophage, B cell, and $\mathrm{T}$ cell functions ${ }^{21,22}$ (Fig. 1: vitamin $\mathrm{D}$ effects on immune system). ${ }^{19}$

The vitamin D receptor (VDR) and vitamin D metabolizing enzymes are expressed by several cells of the immune system like Th1 and Th2 cells. They are the direct targets of the activated form of vitamin $\mathrm{D}, 1,25$ dihydroxyvitamin D3. Indeed, activation of CD4+ T cells results in a five-fold increase in VDR expression, enabling calcitriol to regulate at least 102 identified genes. ${ }^{23}$
Table 6: Correlation of symptoms severity with vitamin D levels

\begin{tabular}{lll}
\hline $\begin{array}{l}\text { Total nasal } \\
\text { symptom score }\end{array}$ & No. of patients & $\begin{array}{l}\text { Mean Vit. } D \\
\text { levels in } \mathrm{ng} / \mathrm{ml}\end{array}$ \\
\hline$>11$ & $9(42.85 \%)$ & 16.88 \\
7 to 10 & $11(52.38 \%)$ & 18.15 \\
3 to 6 & $1(4.76 \%)$ & 26.3 \\
0 to 2 & 0 & 0 \\
\hline
\end{tabular}

This regulatory effect has a downstream impact on the levels of circulating chemokines and cytokines. Th1 cells secrete interferon gamma (IFN $\gamma)$, interleukin (IL)-2, IL-12, and tumor necrosis factor alpha (TNF $\alpha)$, all of which augment the cell-mediated defense against intracellular pathogens. Th2 cells express IL-4, IL-5 and IL-13, which further propagate the Th2 response. These Th2-derived cytokines modulate the immune response against parasites and are also associated with the regulation of atopy and asthma. ${ }^{24,25}$

Vitamin D exerts suppressive effect on the expression of IL-2 and IFN $\gamma$ in a VDR-regulated mechanism. The suppression of IL-2 production, in turn, inhibits T-cell proliferation. Addition of exogenous IL-2 can rescue T-cells from the anti proliferative effects of vitamin D. ${ }^{1}$ Vitamin $\mathrm{D}$ blocks the induction of Th1 cytokines, especially IFN $\gamma$, while simultaneously enhancing Th 2 responses through the enhancement of IL-4 production. ${ }^{26,27}$ Overall, vitamin D decreases cell-mediated immune responses. This suppressive effect on humoral immunity is facilitated through the effect of vitamin D3 on APC. In APCs, calcitriol inhibits the production of IL-12, a cytokine that normally enhances the Th1 response. ${ }^{27}$ In effect, vitamin D acts as a physiologic 'brake' on humoral immunity.

Similarly, vitamin D also inhibits the innate immune system. Vitamin D inhibit the differentiation, maturation, and immune-stimulating ability of dendritic cells by downregulating the expression of MHC class II molecules. ${ }^{20}$ Immature dendritic cells promote T-cell tolerance, whereas mature dendritic cells activate naive $\mathrm{T}$ cells. Physiologic levels of vitamin D inhibit the maturation of dendritic cells and maintain an immature and tolerogenic phenotype with inhibition of activation markers such as MHC class II, CD40, CD80 and CD86 and up regulation of inhibitory molecules.

Vitamin D concurrently suppresses IL-12 and enhances IL-10 production in these dendritic cells. ${ }^{28}$ The net response is a decrease in Th1 responses and proliferation of $\mathrm{T}$ regulator cells which act as a further 'check' on the immune response. The immune response is skewed toward a Th2 response with a significant suppression of the Th1 response. ${ }^{26,27}$ Thus, vitamin D may have a suppressive effect on inflammation at the level of the nasal mucosa, potentially influencing the 
development and propagation of CRS. Interestingly, vitamin $\mathrm{D}$ has also been shown to have a stimulatory effect on monocytes in vitro, suggesting a complex role in immune homeostasis rather than a purely suppressive effect on the immune system. ${ }^{20}$ The extent of this physiologic balance has yet to be fully elucidated.

In our study, patients of allergic rhinitis showed deficiency in vitamin $\mathrm{D}$ indicated by mean vitamin D level of $19.52 \pm 7.35 \mathrm{ng} / \mathrm{ml}$. This result suggests the importance of assessing vitamin D levels in patients of allergic rhinitis. There are other studies recently coming in support of this fact as stated by Saba Arshi et al ${ }^{29}$ The prevalence of severe vitamin $\mathrm{D}$ deficiency was significantly higher in patients with allergic rhinitis than the normal population. In a study performed by Moradzadeh et $\mathrm{al}^{30}$ the prevalence of severe vitamin $\mathrm{D}$ deficiency was significantly greater in patients with allergic rhinitis than the normal population (30\% vs $5.1 \% ; \mathrm{p}=0.03$ ) demonstrating that there is an association between serum vitamin D levels and allergic rhinitis status. These results may indicate subtle differences in terms of vitamin D metabolism or sensitivity in allergic patients, as hypothesized by Wjst et al. ${ }^{31}$

As Bruce W Hollis stated 'The assessment of vitamin D is rapidly becoming an important tool in the diagnosis and management of much diverse pathology $\mathrm{y}^{\prime 32}$ therefore measuring serum levels of vitamin D could be considered in the routine assessment of patients with allergic rhinitis.

Hypponen et $\mathrm{al}^{33}$ showed that $\mathrm{IgE}$ concentrations were higher for participants with low 25(OH) D $(<25 \mathrm{nmlol} / \mathrm{l})$ and with very high $25(\mathrm{OH})$ D serum levels (>135 nmol/l) compared with a reference group (100-125 nmol/1). Thus very low and very high levels are asociated with elevated IgE levels in adults. For allergic diseases like chronic rhinosinusitis, current clinical studies have shown that such patients had $25(\mathrm{OH}) \mathrm{D}$ serum levels that were 40 to $50 \%$ lower than the serum $25(\mathrm{OH}) \mathrm{D}$ levels in the control group. ${ }^{34,35}$ In contrast, the incidence of allergic rhinitis correlated with increasing $25(\mathrm{OH})$ D levels in early studies from 1930 to 1962 long before vitamin $\mathrm{D}$ re-entered the spotlight as an allergy influencing factor. ${ }^{36}$ But still, vitamin D intake above current dietary recommendations was not related with an increased risk of adverse events. ${ }^{37}$

Although, our results are extremely compelling, the study suffers from a small sample size. Future work may extrapolate these data to a larger patient set up and their study, mainly through a prospective study, which would help us to understand the role of vitamin D in the pathophysiology of allergic inflammation. Serum vitamin D levels could, potentially, be added to the routine workup of patients suffering from allergic rhinitis and these data could be used to help determine the disease severity and possibly even treatment.

\section{CONCLUSION}

There is a correlation between serum vitamin $\mathrm{D}$ levels and allergic rhinitis. The level of vitamin D is being low in patients of AR. Therefore measuring of serum levels of vitamin D could be considered in the routine assessment of patients with allergic rhinitis. To further evaluate vitamin D and its relationship to allergic rhinitis, Randomized controlled trials are needed. These findings may then guide researchers to pursue clinical trials aimed at evaluating vitamin D and its analogs as potential therapeutic interventions and addition of vitamin D in the therapeutic regimen for treatment of allergic rhinitis can possibly reduce the severity of the disease and may control the frequent attacks of allergic rhinitis.

\section{ACKNOWLEDGMENT}

The authors would like to acknowledge the support from The Dean and Management of Our Medical College Institute for lapsing the charges of investigation required in the research work.

\section{REFERENCES}

1. Meltzer EO. The prevalence and medical and economic impact of allergic rhinitis in the United States. J Allergy Clin Immunol 1997;99:S805-S828.

2. Bousuet J, Vignola AM, Demoly P. Links between rhinitis and asthma. Allergy 2003 Aug;58(8):691-706.

3. Lima RG, Pastorino AC, Casagrande RR, Sole D, Leone C, Jacob CM. Prevalence of asthma, rhinitis and eczema in 6 to 7 years old students from the western districts of Sao Paulo City, using the standardized questionnaire of the 'International Study of Asthma and Allergies in Childhood' (ISAAC)-phase IIIB. Clinics (Sao Paulo) 2007 Jun;62(3):225-234.

4. Romano-Zelekha O, Graif Y, Garty BZ, Livne I, Green MS, Shohat $\mathrm{T}$. Trends in the prevalence of asthma symptoms and allergic diseases in Israeli adolescents: results from a national survey 2003 and comparison with 1997. J Asthma 2007 Jun;44(5):365-369.

5. Sly RM. Changing prevalence of allergic rhinitis and asthma. Ann Allergy Asthma Immunol 1999 Mar;82(3):233-248.

6. von Mutius E, Weiland SK, Fritzsch C, Duhme H, Keil U. Increasing prevalence of hay fever and atopy among children in Leipzig, East Germany. Lancet 1998 Mar 21;351(9106): 862-866.

7. A comparative review of the burden, prevalence, knowledge about allergic rhinitis between the US and India; 9 December 2012. Muntajibuddin Arif Ahmed, MD , Paediatric and Allergy, Masha Medical Center, Hyderabad, India.

8. Seasonal allergies: Something to sneeze at. Available at: http://www.cbc.ca/health/story/ 2010/03/19/f-seasonalallergiessymptoms.

9. Mithal A1, Wahl DA, Bonjour JP, Burckhardt P, DawsonHughes B, Eisman JA, El-Hajj Fuleihan G, Josse RG, Lips 
P, Morales-Torres J. IOF Committee of Scientific Advisors (CSA) Nutrition Working Group. Global vitamin D status and determinants of hypovitaminosis D. Osteoporosis Int 2009 Nov;20(11):1807-1820.

10. Schauber J, Gallo RL. Vitamin D deficiency and asthma: not a strong link yet. J Allergy Clin Immunol 2008 Mar;121(3): 782-783.

11. Litonjua AA, Weiss ST. Is vitamin D deficiency to blame for the asthma epidemic? J Allergy Clin Immunol 2007 Nov;120(5):1031-1035.

12. Clifford RL, Knox AJ. Vitamin D: a new treatment for airway remodelling in asthma? Br J Pharmacol 2009 Nov;158(6): 1426-1428.

13. Sidbury R, Sullivan AF, Thadhani RI, Camargo CA Jr. Randomized controlled trial of vitamin D supplementation for winter-related atopic dermatitis in Boston: a pilot study. Br J Dermatol 2008 Jul;159(1):245-247.

14. Özgür A, Arslanoğlu S, Etıt D, Demıray U, Önal HK. Comparison of nasal cytology and symptom scores in patients with seasonal allergic rhinitis, before and after treatment. J Laryngol Otol 2011 Oct;125(10):1028-1032.

15. Heaney RP. Vitamin D depletion and effective calcium absorption. J Bone Min Res 2003 Jul;18(7):1342.

16. Dykewicz MS, Fineman S, Skoner DP, Nicklas R, Lee R, Blessing-Moore J, Li JT, Bernstein IL, Berger W, Spector S, et al. Diagnosis and management of rhinitis: complete guidelines of the Joint Task Force on Practice Parameters in Allergy, Asthma and Immunology. American Academy of Allergy, Asthma, and Immunology. Ann Allergy Asthma Immunol 1998 Nov;81(5 Pt 2):478-518.

17. Howarth PH. Eosinophils and rhinitis. Clin Exp Allergy 2005;5:55-63.

18. Varney VA, Jacobson MR, Sudderick RM, Robinson DS, Irani AM, Schwartz LB, Mackay IS, Kay AB, Durham SR. Immunohistology of the nasal mucosa following allergeninduced rhinitis: Identification of activated T lymphocytes, eosinophils, and neutrophils. Am Rev Respir Dis 1992 Jul; 146(1):170-176.

19. Mora JR, Iwata M, von Andrian UH. Vitamin effects on the immune system: vitamins A and D take centre stage. Nat Rev Immunol 2008 Sep;8(9):685-698.

20. Chanda R, Aggarwal AK, Kohli GS, Jaswal TS, Gupta KB. Comparative study of nasal smear and biopsy in patients of allergic rhinitis. Indian J Allergy Asthma Immunol 2002; 16(1):27-31

21. Mulligan JK, Bleier BS, O'Connell B, Mulligan RM, Wagner C, Schlosser RJ. Vitamin D3 correlates inversely with systemic dendritic cell numbers and bone erosion in chronic rhinosinusitis with nasal polyps and allergic fungal rhinosinusitis. Clin Exp Immunol 2011 Jun;164(3):312-320.

22. Wolff AE, Jones AN, Hansen KE. Vitamin D and musculoskeletal health. Nat Clin Pract Rheumatol 2008 Nov;4(11): 580-588.
23. Mahon B, Wittke A, Weaver V, Cantorna M. The targets of vitamin $\mathrm{D}$ depend on the differentiation and activation status of CD4 positive T cells. J Cell Biochem 2003 Aug 1;89(5): 922-932.

24. Penna G, Roncari A, Amuchastegui S, Daniel KC, Berti E, Colonna M, Adorini L. Expression of the inhibitory receptor ILT3 on dendritic cells is dispensable for induction of CD4+Foxp3+ regulatory $\mathrm{T}$ cells by 1,25-dihydroxyvitamin D3. Blood 2005 Nov 15;106(10):3490-3497.

25. Cantorna MT, Zhu Y, Froicu M, Wittke A. Vitamin D status, 1,25-dihydroxyvitamin D3, and the immune system. Am J Clin Nutr 2004 Dec;80(6 Suppl):1717s-1720s.

26. Kamen DL, Tangpricha V. Vitamin D and molecular actions on the immune system: modulation of innate and autoimmunity. J Mol Med (Berl) 2010 May;88(5):441-450.

27. Dimeloe S, Nanzer A, Ryanna K, Hawrylowicz C. Regulatory $T$ cells, inflammation and the allergic response-The role of glucocorticoids and Vitamin D. J Steroid Biochem Mol Biol 2010 May 31;120(2-3):86-95.

28. Wang TT, Nestel FP, Bourdeau V, Nagai Y, Wang Q, Liao J, Tavera-Mendoza L, Lin R, Hanrahan JW, Mader S, White JH. Cutting edge: 1,25-dihydroxyvitamin D3 is a direct inducer of antimicrobial peptide gene expression. J Immunol 2004 Sep 1;173(5):2909-2912.

29. Arshi S, Ghalehbaghi B, Kamrava SK, Aminlou M. Vitamin D serum levels in allergic rhinitis: any difference from normal population? Asia Pac Allergy 2012 Jan;2(1):45-48.

30. Moradzadeh K, Larijan B, Keshtkar AA, Hossein-Nezhad A, Rajabian R, Nabipour I, Omrani GH, Bahrami A, Gooya MM, Delavari A. Normative values of vitamin D among Iranian population: a population based study. Int J Osteoporosis Metab Disorders 2008;1(1):8-15.

31. Wjst M, Hypponen E. Vitamin D serum levels and allergic rhinitis. Allergy 2007;62:1085-1086.

32. Hollis BW. Assessment of vitamin D status and definition of a normal circulating range of 25-hydroxyvitamin D. Curr Opin Endocrinol Diabetes Obestet 2008;15:489-494.

33. Hypponen E, Berry DJ, Wjst M, Power C. Serum 25-hydroxyvitamin $\mathrm{D}$ and $\mathrm{Ig} \mathrm{E}-\mathrm{a}$ significant but nonlinear relationship. Allergy Eur J Allergy ClinAsImmunol 2009 Apr; 64(4):613-620.

34. Pinto JM, Schneider J, Perez R, DeTineo M, Baroody FM, Naclerio RM. Serum 25-hydroxyvitamin D levels are lower in urban African American subjects with chronic rhinosinusitis. J Allergy Clin Immunol 2008 Aug;122(2):415-417.

35. Deverrux G, Wilson A, Avenell A, McNeill G, Fraser WD. A case-control study of vitamin D status and asthma in adults. Allergy 2010 May;65(5):666-667.

36. Wjst M. Introduction of oral vitamin D supplementation and the rise of the allergy pandemic. Allergy Asthma Clin Immunol 2009 Nov 19;5(1):8.

37. Cranney A, Horsley T, O’Donnell S, Weiler H, Puil L, Ooi D, Atkinson S, Ward L, Moher D, Hanley D, et al. Effectiveness and safety of vitamin D in relation to bone health. Evid Rep Technol Assess (Full Rep) 2007 Aug;(158):1-235. 